Original Paper

\title{
Study on Impact Mechanism for Beef Cattle Farming and Importance of Evaluating Agricultural Information in Korea Using DEMATEL, PCA and AHP
}

\author{
Yong-hun Kim*
}

The United Graduate School of Agricultural Sciences, Tottori University, Tottori 680-8553, Japan

\begin{abstract}
The dual-fold purpose of this study was to investigate whether there was a correlation between agricultural information and beef cattle farming and to analyze what improving information services had an effect on beef cattle farming. Evaluations of the impact mechanism between beef cattle farming and prevailing conditions were fundamentally the same for the farmers or the civil servants and staff members of PAIs(Public Agricultural Institutions). All information elements had large and minus relation index values. Both responding groups thought that the change in elements involving beef cattle farming easily improved information services, whereas it did not strongly affect beef cattle farming or prevailing conditions. The Decision-Making and Evaluation Laboratory (DEMATEL) method, which separates the interacting elements of a system into cause and effect groups as a structural modeling approach, is a good technique for analyzing the correlation between pairs of elements. Principal Component Analysis (PCA) was applied to the total relation matrix to find out the extent of the cause-effect relationship on the results. The features or correlations within all elements, based on patterns of similarity between the cause or effect groups, were confirmed. The evaluation of the information itself in the AHP(Analytic Hierarchy Process) results was not the same as the magnitude of its impacts in the DEMATEL analysis. However, a serious problem is that improving information services did not affect beef cattle farming or prevailing conditions. It was established that the correlations or potential structures between pairs of elements could be confirmed more easily, in detail, by applying PCA to the total relation matrix.
\end{abstract}

Keywords

information service, beef cattle farming, DEMATEL, PCA, AHP.

Introduction

Information technology has recently expanded rapidly to various fields of industry throughout Korea. The need for a new way of organizing information is required in the agricultural industry, including the livestock industry, as both its supply and demand has significantly changed since the market was opened. To date, land, labor, and natural phenomena have been the most important factors in agricultural *Corresponding Author E-mail: carfinkim@hotmail.com management, but now, agricultural information and knowledge, which assist competitiveness and business rationalization, have become more important. Speedy acquisition of agricultural information could help to increase agricultural income and efficiency through product inventories or shipping control and improve agricultural competitiveness. Therefore, the Korean Ministry of Agriculture and Forestry (KMAF) has tried to develop an agricultural information program that was based on the "Plan for construction of comprehensive 
agricultural and forestry information network" . Thirteen agricultural institutions have participated since 1993 (KMAF 1998; Kang 2002).

The livestock industry, which accounts for more than $20 \%$ of agricultural production, is very important in Korea. Native Korean cattle are the main domestic animal in the Korean livestock industry and constitute a very large proportion of Korean farmers' incomes. For many years, beef consumption in Korea has steadily increased due to the increase in national income and economic growth. However, there have not been sufficient investigations into how much the supply of and improvement in agricultural information services affect beef cattle farming and the circumstances that surround it. The supply of and improvement in agricultural information not only affect various other factors but are also affected by them.

The Decision-Making and Evaluation Laboratory (DEMATEL) method, which separates interacting elements of a system into cause and effect groups, as a structural modeling approach, is a good technique for analyzing the impact of agricultural information. However, not many studies have applied the DEMATEL method in Korea, and agricultural research including related beef cattle farming one has not shown how it has been applied. Cho (2002) used his comparison of DEMATEL method and $\mathrm{KJ}$ theory how design factors were structured. Hwang and Lee (2002) evaluated how many in the aged population went to resorts by applying the DEMATEL method. Oh et al. (1998) studied planning in mountainous Korean and Japanese cities with DEMATEL and quantification theory.

The dual-fold purpose of this study was to investigate whether there was a correlation between agricultural information and beef cattle farming or prevailing conditions, and to analyze what the supply of and improvement in information services had an effect on beef cattle farming with the DEMATEL method. Moreover, features or

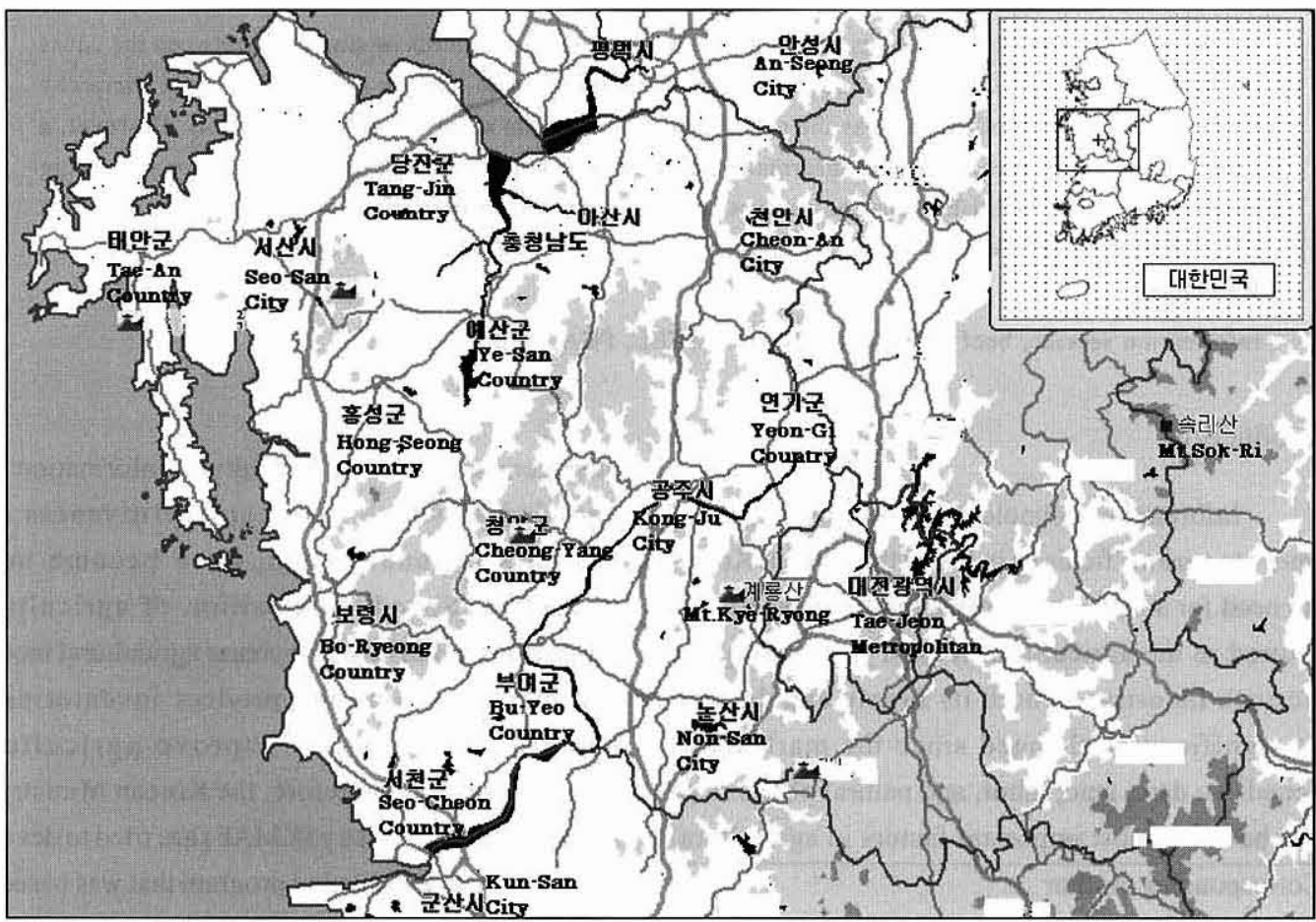

Fig. 1 Location of Non-san 
correlations that were based on similarities in cause element groups or effect element groups were confirmed by applying Principal Component Analysis (PCA) to the total relation matrix.

Investigated area

The field survey for the DEMATEL analysis was conducted in Non-san, a city in Chung-nam province, Korea. Non-san lies to the southwest of the metropolis of Dea-jeon (Fig. 1), which has a population of more than $1,450,000$ people. Livestock farming is a very important industry in Non-san, where livestock represents more than $25 \%$ of the total agricultural product. Many meat-processing factories are also located there.

Farmers and public agricultural institutions (PAIs) may differently evaluate what agricultural information has an effect on beef cattle farming and prevailing conditions. Therefore, evaluations of the effects of agricultural information by seven farmers and seven civil servants or staff members of PAIs, which were the Non-san Agriculture Technology Center (NATC) and Agricultural Cooperative Association (ACA), were assessed in this study to determine whether they were different.

The average age of the farmers was 51.86 , the average number of cattle being raised per farmer was 61.43 , and the average area of cultivated land was 1.09ha. An average of two family members was engaged in raising cattle. The average age of the civil servants or staff members of PAIs was 41.57 , and they were in charge of agricultural management or providing advice on livestock. Their average length of service was 13.86 years.

\section{Application Method and Elements of Beef Cattle Farming Mechanism}

DEMATEL is a practical and useful method of examining the structure of complicated causal and contextual relationships between the elements of a system. We first extracted all the elements that belonged to beef cattle farming. Figure 2 shows part of a survey sheet. Some sub-elements considered to have no relationships were removed to reduce the frequency of answers. The pair-wise comparison scale was assigned six levels, where the scores $0,1,2,3,4$, and 5 meant "No influence", "Very low influence", "Low influence", "Medium influence", "High influence", and "Very high influence". We next focused on the strength of relationships between elements and tried to find this for all pairs of elements (Hoshino 1992). The results were calculated with the arithmetical mean of five relationship strengths after removing the maximum and minimum values. The initial direct-relation matrix $Z$ was an $n \times n$ matrix obtained by pair-wise comparisons in terms of influences and directions of elements, in which $z_{i j}$ was the degree to which element $C_{i}$ affected element $C_{j}$ (Lin and $\mathrm{Wu} 2004)$. As a result, all principal diagonal

\section{Survey of Impact Mechanism on Beef cattle farming}

Please check whether these elements have direct effects on the next subelements. If they have direct effects, to what degree.

\begin{tabular}{|c|c|c|c|c|c|c|}
\hline Elements & \multirow{2}{*}{$\mathbf{N}$} & \multirow{2}{*}{\multicolumn{2}{|c|}{$\mathbf{L}$}} & \multirow{2}{*}{$\mathbf{M}$} & & \\
\hline 1. Fall in beef price & & & & & & \\
\hline 2. Fall in price of calves & 0 & 1 & 2 & 3 & 4 & 5 \\
\hline 8. Increase in national demand for beef & 0 & 1 & 2 & 3 & 4 & 5 \\
\hline 11. Stagnation of local economy & 0 & 1 & 2 & 3 & 4 & 5 \\
\hline 12. Improving information service for domestic and imported beef & 0 & 1 & 2 & 3 & 4 & 5 \\
\hline 13. Improving information service for beef prices & 0 & 1 & 2 & 3 & 4 & 5 \\
\hline 14. Improving information service for price of calves & 0 & 1 & 2 & 3 & 4 & 5 \\
\hline
\end{tabular}

Fig. 2 Example questions on effect of elements 
elements $z_{i j}$ of matrix $Z$ were set to zero.

obtained by

$X=\frac{Z}{s}$

$\begin{array}{llll}\mathrm{C}_{1} & \mathrm{C}_{2} & \cdots & \mathrm{C}_{\mathrm{n}}\end{array}$

$Z=\underset{\mathrm{C}_{2}}{\mathrm{C}_{1}}\left[\begin{array}{cccc}0 & \mathrm{z}_{12} & \cdots & \mathrm{z}_{1 \mathrm{n}} \\ \mathrm{C}_{\mathrm{n}}\end{array}\left[\begin{array}{cccc}\mathrm{z}_{21} & 0 & \cdots & \mathrm{z}_{2 \mathrm{n}} \\ \vdots & \vdots & \ddots & \vdots \\ \mathrm{z}_{\mathrm{n} 1} & \mathrm{z}_{\mathrm{n} 2} & \cdots & 0\end{array}\right]\right.$

where $s=\max _{1 \leq i \leq n}\left(\sum_{j=1}^{n} z_{i j}\right)$,

Total relation matrix $\mathrm{T}$ can be obtained by

$$
T=\lim _{k \rightarrow \infty}\left(X+X^{2}+\cdots X^{k}\right)=X(I-X)^{-1}
$$

Table 1 Elements of beef cattle farming, prevailing conditions, and agricultural information

\begin{tabular}{|c|c|}
\hline \multicolumn{2}{|c|}{ 1) Market conditions } \\
\hline $\mathrm{x}_{1} \mathrm{FBP}$ & Fall in beef prices \\
\hline $\mathrm{x}_{2} \mathrm{FCP}$ & Fall in calf prices \\
\hline $\mathrm{x}_{3} \mathrm{ILC}$ & Increase in labor costs \\
\hline $\mathrm{x}_{4}$ RIFGP & Rise in imported feed or grain prices \\
\hline $\mathrm{x}_{5} \mathrm{TL}$ & Trade liberalization \\
\hline $\mathrm{x}_{6}$ OBSE & Outbreak of BSE \\
\hline $\mathrm{x}_{7} \mathrm{RGNP}$ & Rise in GNP \\
\hline $\mathrm{x}_{8} \mathrm{INDB}$ & Increase in national demand for beef \\
\hline $\mathrm{x}_{9} \mathrm{UBI}$ & Urbanization near beef industry \\
\hline $\mathrm{x}_{10} \mathrm{IBS}$ & Increase in beef supply \\
\hline $\mathrm{x}_{11} \mathrm{SLE}$ & Stagnation of local economy \\
\hline \multicolumn{2}{|c|}{ 2) Agricultural information } \\
\hline $\mathrm{x}_{12}$ IDIBIS & Improving domestic and imported beef information services \\
\hline $\mathrm{x}_{13}$ IBPIS & Improving beef price information services \\
\hline $\mathrm{x}_{14}$ ICPIS & Improving calf price information services \\
\hline $\mathrm{x}_{15}$ IPIS & Improving policy information services \\
\hline $\mathrm{x}_{16}$ IITMIS & Improving industrial technology and material information services \\
\hline $\mathrm{x}_{17}$ IDIS & Improving disease information services \\
\hline \multicolumn{2}{|c|}{ 3) Agricultural policy } \\
\hline $\mathrm{x}_{18} \mathrm{RTL}$ & Relaxing terms for loans \\
\hline $\mathrm{x}_{19}$ IALL & Increasing activities at local level \\
\hline $\mathrm{x}_{20}$ IPSP & Implementating or improving price stabilization or support policy \\
\hline $\mathrm{x}_{21} \mathrm{DPD}$ & Deregulating production or distribution \\
\hline \multicolumn{2}{|c|}{ 4) Livestock technology } \\
\hline $\mathrm{x}_{22} \mathrm{TAF}$ & Technological advances in fattening \\
\hline $\mathrm{x}_{23} \mathrm{TAB}$ & Technological advances in breeding \\
\hline $\mathrm{x}_{24} \mathrm{TACF}$ & Technological advances in cultivating feed \\
\hline \multicolumn{2}{|c|}{ 5) Beef management condition } \\
\hline $\mathrm{x}_{25} \mathrm{ABF}$ & Aging beef farmers \\
\hline $\mathrm{x}_{26} \mathrm{RNBF}$ & Reduced number of beef farmers \\
\hline $\mathrm{x}_{27} \mathrm{ISBF}$ & Increased scale of beef cattle farming \\
\hline $\mathrm{x}_{28} \mathrm{ICBF}$ & Improved capabilities of beef farmers \\
\hline $\mathrm{x}_{29} \mathrm{RPC}$ & Reduced of production costs \\
\hline $\mathrm{x}_{30} \mathrm{IIBF}$ & Increased income of beef farmers \\
\hline $\mathrm{x}_{31} \mathrm{IMQ}$ & Improved meat quality \\
\hline $\mathrm{x}_{32} \mathrm{ILP}$ & Increased livestock pollution \\
\hline $\mathrm{x}_{33}$ INFSJ & Increased number of farmers with second job \\
\hline $\mathrm{x}_{34} \mathrm{DCF}$ & Decreased cultivation of feed \\
\hline
\end{tabular}


There are many elements in beef cattle farming. In this study, these were classified into five categories and subdivided into 34 elements. Those 34 elements were determined by a Korean Rural Economic Institute researcher who was in charge of the Livestock Division, and these are the same as those listed in Table 1.

\section{DEMATEL Results}

The row-sum, column-sum, relation index, and influence index for the DEMATEL results for livestock farmers and civil servants or staff members of PAIs are listed in Table 2.

$D_{i}$, the sum of rows, means the total influence element is having on the others, both directly and indirectly, and $R_{i}$, the sum of the columns, means the total influence the others are having on element. The relation index, which was obtained by adding $R_{i}$ to $D_{i}$, shows how important element $i$ is, whereas the influence index, which was obtained by subtracting $R_{i}$ from $D_{i}$, can divide elements into cause and effect groups. All information elements had large relation index values $\left(D_{i}+R_{i}\right)$ which were more than the average and were important. However, all their influence index values $\left(D_{i}-R_{i}\right)$ were negative and they therefore belonged to the effect group (Monma 1992). Farmers thought that changed elements in the prevailing conditions for beef cattle farming easily affected information services, whereas information did not affect beef cattle farming or prevailing conditions. The $D_{i}$ for $\mathrm{x}_{12}$ IDIBIS, $\mathrm{x}_{13}$ IBPIS, $\mathrm{x}_{14}$ ICPIS, $\mathrm{x}_{15}$ IPIS, and $x_{17}$ IDIS were less than the average value for rowsum (1.545). Only the row-sum for $x_{16}$ IITMIS (1.717) was more than the average value for rowsum, which had a relatively strong influence $\left(t_{i j}{ }_{-}\right.$ 0.100 ) on $x_{19}$ IALL, $x_{27}$ ISBF, $x_{28}$ ICBF, and $x_{30}$ IIBF. Prevailing market elements, which were $x_{4}$ RIFGP and $x_{5} T L$, and domestic economic development elements, which were $x_{3}$ ILC, $x_{7}$ RGNP, $x_{8}$ INDB, and $x_{9}$ UBI, belonged to the cause group. $x_{30}$ IIBF and $\mathrm{x}_{19}$ IALL belonged to the effect group.

All information elements had a large relation index for civil servants or staff members of PAIs, like the results for farmers, which were more than average (3.334) and which indicated importance. However, all their influence index values were negative and they therefore belonged to the effect group. The civil servants or staff members of PAIs also considered that changed conditions in beef cattle farming affected information services, whereas information did not affect beef cattle farming or prevailing conditions. Farmers and civil servants or staff members of PAIs basically evaluated the impact mechanisms for beef cattle farming and prevailing conditions the same. However, whereas the row-sum for $\mathrm{x}_{16}$ IITMIS for the former group was more than average, all information elements for the latter was less than the average for row-sums (1.667) and they were not more than 0.100 of the total relation elements. Prevailing market elements such as $\mathrm{x}_{4}$ RIFGP, $\mathrm{x}_{5} \mathrm{TL}$, and $\mathrm{x}_{6} \mathrm{OBSE}$, and the domestic economic development elements, which were $x_{3}$ ILC, $x_{7}$ RGNP, $x_{8}$ INDB, and $x_{9}$ UBI, belonged to the cause group as in the results for farmers. $\mathrm{x}_{30}$ IIBF and $\mathrm{x}_{19}$ IALL belonged to the effect group.

PCA Results

Results based on the relation index and influence index could be considered with the original DEMATEL method (Tamura et al. 2003). The general positioning of all elements in the total system could be confirmed by applying this, whereas it was difficult to evaluate features that were based on the cause-effect relationships of all elements. PCA was applied here to the total relation matrix to find out what effect the cause-effect relationship had on the results. The features or correlations within all elements, based on their similarities with cause or effect groups, were then confirmed. This was an application of the method of functional area division that applied PCA to the Origin-Destination (OD) matrix discussed in the geographical researches (William and Duane 1963; Paul 1975). The total relation matrix can be regarded as an OD matrix because it consists of data on the strength of the cause-effect relationship. There are frequent occasions when the inverse of the 
Table 2 DEMATEL Results

\begin{tabular}{|c|c|c|c|c|c|c|c|c|}
\hline \multirow[t]{2}{*}{ Elements } & \multicolumn{2}{|c|}{$\begin{array}{l}\text { Row sum } \\
\text { (D) }\end{array}$} & \multicolumn{2}{|c|}{$\begin{array}{l}\text { Column sum } \\
\text { (R) }\end{array}$} & \multicolumn{2}{|c|}{$\begin{array}{c}\text { Relation index } \\
(\mathrm{D}+\mathrm{R})\end{array}$} & \multicolumn{2}{|c|}{$\begin{array}{l}\text { Influence index } \\
\text { (D-R) }\end{array}$} \\
\hline & Farmers & PAIs & Farmers & PAIs & Farmers & PAIs & Farmers & PAIs \\
\hline $\mathrm{x}_{1}$ FBP & 1.875 & 2.001 & 1.121 & 1.461 & 2.996 & 3.462 & 0.754 & 0.541 \\
\hline $\mathrm{x}_{2} \mathrm{FCP}$ & 1.659 & 1.949 & 1.137 & 1.539 & 2.795 & 3.488 & 0.522 & 0.411 \\
\hline $\mathrm{x}_{3}$ ILC & 1.656 & 2.020 & 0.523 & 0.570 & 2.179 & 2.590 & 1.134 & 1.450 \\
\hline $\mathrm{x}_{4}$ RIFGP & 1.533 & 1.860 & 0.367 & 0.335 & 1.900 & 2.195 & 1.167 & 1.525 \\
\hline $\mathrm{x}_{5} \mathrm{TL}$ & 2.507 & 2.459 & 1.310 & 1.393 & 3.817 & 3.852 & 1.197 & 1.066 \\
\hline $\mathrm{x}_{6}$ OBSE & 1.467 & 1.825 & 0.636 & 0.720 & 2.103 & 2.545 & 0.831 & 1.106 \\
\hline $\mathrm{x}_{7}$ RGNP & 1.997 & 2.232 & 0.412 & 0.293 & 2.409 & 2.525 & 1.584 & 1.940 \\
\hline $\mathrm{x}_{8}$ INDB & 2.176 & 2.289 & 0.974 & 0.989 & 3.151 & 3.277 & 1.202 & 1.300 \\
\hline $\mathrm{x}_{9} \mathrm{UBI}$ & 1.387 & 1.770 & 0.202 & 0.358 & 1.589 & 2.128 & 1.186 & 1.412 \\
\hline $\mathrm{x}_{10}$ IBS & 1.915 & 2.237 & 1.986 & 2.224 & 3.901 & 4.460 & -0.071 & 0.013 \\
\hline $\mathrm{x}_{11} \mathrm{SLE}$ & 0.809 & 0.852 & 0.734 & 0.764 & 1.543 & 1.616 & 0.076 & 0.089 \\
\hline $\mathrm{x}_{12}$ IDIBIS & 1.450 & 1.525 & 2.726 & 3.012 & 4.176 & 4.537 & -1.276 & -1.487 \\
\hline $\mathrm{x}_{13}$ IBPIS & 1.170 & 1.237 & 2.451 & 2.749 & 3.620 & 3.987 & -1.281 & -1.512 \\
\hline $\mathrm{x}_{14}$ ICPIS & 0.989 & 1.177 & 2.467 & 2.602 & 3.455 & 3.779 & -1.478 & -1.424 \\
\hline $\mathrm{x}_{15}$ IPIS & 1.208 & 1.288 & 2.510 & 2.853 & 3.718 & 4.141 & -1.303 & -1.564 \\
\hline $\mathrm{x}_{16}$ IITMIS & 1.717 & 1.596 & 2.924 & 3.241 & 4.641 & 4.837 & -1.207 & -1.645 \\
\hline $\mathbf{x}_{17}$ IDIS & 1.201 & 1.363 & 2.164 & 2.363 & 3.365 & 3.726 & -0.963 & -1.000 \\
\hline $\mathrm{x}_{18} \mathrm{RTL}$ & 1.356 & 1.351 & 1.700 & 1.652 & 3.056 & 3.003 & -0.345 & -0.301 \\
\hline $\mathrm{x}_{19}$ IALL & 1.048 & 1.059 & 2.442 & 2.375 & 3.490 & 3.434 & -1.395 & -1.317 \\
\hline $\mathrm{x}_{20}$ IPSP & 1.115 & 1.015 & 0.908 & 1.108 & 2.023 & 2.123 & 0.207 & -0.092 \\
\hline $\mathrm{x}_{21} \mathrm{DPD}$ & 1.632 & 1.689 & 1.659 & 2.052 & 3.291 & 3.741 & -0.027 & -0.362 \\
\hline $\mathrm{x}_{22} \mathrm{TAF}$ & 1.948 & 1.968 & 2.017 & 2.027 & 3.964 & 3.995 & -0.069 & -0.059 \\
\hline $\mathrm{x}_{23} \mathrm{TAB}$ & 1.752 & 1.928 & 2.101 & 2.153 & 3.853 & 4.081 & -0.349 & -0.225 \\
\hline $\mathrm{x}_{24} \mathrm{TACF}$ & 1.604 & 1.698 & 1.376 & 1.413 & 2.980 & 3.111 & 0.228 & 0.285 \\
\hline $\mathrm{x}_{25} \mathrm{ABF}$ & 1.211 & 1.302 & 0.473 & 0.790 & 1.684 & 2.092 & 0.739 & 0.512 \\
\hline $\mathrm{x}_{26} \mathrm{RNBF}$ & 1.843 & 1.826 & 0.915 & 1.074 & 2.758 & 2.900 & 0.929 & 0.753 \\
\hline $\mathrm{x}_{27} \mathrm{ISBF}$ & 2.474 & 2.696 & 2.568 & 2.608 & 5.042 & 5.304 & -0.094 & 0.089 \\
\hline $\mathrm{x}_{28} \mathrm{ICBF}$ & 1.963 & 2.089 & 2.696 & 2.918 & 4.660 & 5.007 & -0.733 & -0.829 \\
\hline $\mathrm{x}_{29} \mathrm{RPC}$ & 1.708 & 2.157 & 1.974 & 2.126 & 3.681 & 4.283 & -0.266 & 0.031 \\
\hline $\mathrm{x}_{30}$ IIBF & 1.254 & 1.353 & 2.696 & 2.626 & 3.950 & 3.979 & -01.442 & -1.273 \\
\hline $\mathrm{x}_{31} \mathrm{IMQ}$ & 1.582 & 1.520 & 2.289 & 2.014 & 3.871 & 3.533 & -0.707 & -0.494 \\
\hline $\mathrm{x}_{32}$ ILP & 1.533 & 1.580 & 0.789 & 0.813 & 2.322 & 2.394 & 0.744 & 0.767 \\
\hline $\mathrm{x}_{33}$ INFSJ & 1.139 & 1.064 & 0.707 & 0.756 & 1.846 & 1.820 & 0.432 & 0.307 \\
\hline $\mathrm{x}_{34} \mathrm{DCF}$ & 0.665 & 0.699 & 0.589 & 0.710 & 1.254 & 1.409 & 0.075 & -0.010 \\
\hline Average value & 1.545 & 1.667 & 1.545 & 1.667 & 3.091 & 3.334 & -0.000 & -0.000 \\
\hline
\end{tabular}


correlation matrix is used to calculate the loadings for factor analysis. It is impossible to calculate the factor loading when there are the same number of samples and variables. Therefore, PCA was applied here. In all PCAs of farmers and civil servants or staff members of PAIs, seven principal components (PCs) with eigenvalues greater than 1.0 , explain $77.1 \%$ and $79.8 \%$ of the total variance, respectively, as listed in Table 3. The Varimax rotation method with Kaiser Normalization was used.

The top three results for farmers were as follows. In the PCA results, the similarities among factor loadings and those among sample scores respectively express those among cause or effect elements. Both factor loadings and sample scores are necessary to understand both similarities. Therefore, two kinds of values were evaluated.

【First PC】 The first PC was characterized by information elements and some other elements. Four information elements, which were $x_{14}$ ICPIS, $x_{13}$ IBPIS, $x_{12}$ IDIBIS, and $x_{17}$ IDIS, had similarities in their cause and effect elements. According to the results for the total relation matrix, the cause elements were $x_{5}$ TL, $x_{8}$ INDB, and $x_{27}$ ISBF, and those for prevailing conditions or the increased scale of beef cattle farming were related to the improvement in information services. The $x_{28}$ ICBF, $x_{22}$ TAF, $x_{23}$ TAB, and $x_{19}$ IALL elements were similar to the previous four information elements in the cause groups. While the previous four information elements exerted a small influence on the other elements, they had a relatively strong influence on $x_{10}$ IBS, $x_{19}$ IALL, $x_{27}$ ISBF, $x_{30}$ IIBF, and $x_{31}$ IMQ. Although the degree of influence was low, the improvement in information services including $x_{16}$ IITMIS had a direct or indirect influence on improved beef cattle farming or local activities. Information elements also had a relatively strong influence on one another. However, $\mathrm{x}_{16}$ IITMIS, in which the cause elements were $\mathrm{x}_{1}$ FBP,$x_{5}$ TL, $x_{8}$ INDB, $x_{10}$ IBS, $x_{22}$ TAF, $x_{23}$ TAB, $x_{27}$ ISBF, and $x_{28}$ ICBF, had many cause elements compared with the other five information elements.
In other words, although it had a pattern similar to that of the effect elements, it had been affected by more elements than the other five information elements.

【Second PC】 The second PC was characterized by several elements. Of these, $x_{26}$ RNBF, $x_{34}$ DCF, $x_{11}$ SLE, and $x_{33}$ INFSJ had similar cause and effect elements. However, $x_{30}$ IIBF had different cause and effect elements because these reflected the differences between the two types of elements, which were positive and negative attitudes to beef cattle farming.

【Third PC】The third PC, which was characterized by x29 RPC, $x 10$ IBS, $x_{27}$ ISBF, $x_{31}$ IMQ, and some other elements, had similar cause and effect elements.

The results for civil servants or staff members of PAIs are as follows.

【First PC】The elements $x_{27}$ ISBF, $x_{10}$ IBS, and $x_{29}$ RPC had similar cause and effect elements. However, the effect elements from those three were very different from those from $x_{17}$ IDIS.

【Second PC】 The six information elements had similar cause elements for the second PC. Specifically based on the results for the total relation matrix, these six information elements were strongly affected by $x_{5} T L, x_{6}$ OBSE, $x_{8}$ INDB, $x_{27}$ ISBF, $x_{28}$ ICBF, and $x_{29}$ RPC. There were many cause elements compared with the farmers. The four information elements $x_{12}$ IDIBIS, $x_{13}$ IBPIS, $x_{14}$ ICPIS, and $x_{17}$ IDIS had similar effect elements, which were $x_{10}$ IBS, $x_{19}$ IALL, $x_{27}$ ISBF, $x_{28}$ ICBF, and $x_{30}$ IIBF. The other two information elements $\mathrm{x}_{15}$ IPIS and $\mathrm{x}_{16}$ IITMIS also had a relatively strong influence on the above effect elements. Although the degree of influence was not strong, six kinds of information elements also had an influence on improved beef cattle farming or local activities and a relatively strong influence on one another.

【Third PC】 The third PC, which was characterized by $x_{11}$ SLE, $x_{26}$ RNBF, $x_{20}$ IPSP, $x_{34}$ DCF, $x_{33}$ INFSJ, and $x_{6}$ OBSE, had similar cause elements. Of these, elements $x_{20}$ IPSP, $x_{26}$ RNBF, and $x_{11}$ SLE also had 
Table 3 PCA Results

\begin{tabular}{|c|c|c|c|c|c|c|c|}
\hline Farmer & PC1 & $\mathrm{PC} 2$ & PC3 & PC4 & PC5 & PC6 & PC7 \\
\hline $\begin{array}{c}\text { Eigenvalue } \\
\text { Proportion (\%) } \\
\text { Accumulated P. (\%) }\end{array}$ & $\begin{array}{r}7.873 \\
23.155 \\
23.155 \\
\end{array}$ & $\begin{array}{r}4.972 \\
14.624 \\
37.780 \\
\end{array}$ & $\begin{array}{r}4.834 \\
14.217 \\
51.997 \\
\end{array}$ & $\begin{array}{r}2.910 \\
8.557 \\
60.554 \\
\end{array}$ & $\begin{array}{r}2.362 \\
6.948 \\
67.502 \\
\end{array}$ & $\begin{array}{r}1.783 \\
5.244 \\
72.746 \\
\end{array}$ & $\begin{array}{r}1.467 \\
4.314 \\
77.060 \\
\end{array}$ \\
\hline $\begin{array}{l}\text { Factor } \\
\text { Loadings }\end{array}$ & $\begin{array}{ll}\mathrm{x}_{14} & 0.883 \\
\mathrm{x}_{13} & 0.866 \\
\mathrm{x}_{12} & 0.835 \\
\mathrm{x}_{17} & 0.736 \\
\mathrm{x}_{28} & 0.734 \\
\mathrm{x}_{22} & 0.689 \\
\mathrm{x}_{23} & 0.680 \\
\mathrm{x}_{19} & 0.642 \\
\mathrm{x}_{15} & 0.627 \\
\mathrm{x}_{21} & 0.606\end{array}$ & $\begin{array}{rr}\mathrm{x}_{26} & 0.934 \\
\mathrm{x}_{34} & 0.855 \\
\mathrm{x}_{11} & 0.804 \\
\mathrm{x}_{33} & 0.738 \\
\mathrm{x}_{25} & 0.628 \\
\mathrm{x}_{20} & 0.555 \\
\mathrm{x}_{6} & 0.513 \\
\mathrm{x}_{30} & -0.211\end{array}$ & $\begin{array}{ll}\mathrm{x}_{29} & 0.783 \\
\mathrm{x}_{10} & 0.706 \\
\mathrm{x}_{27} & 0.683 \\
\mathrm{x}_{31} & 0.661 \\
\mathrm{x}_{30} & 0.606 \\
\mathrm{x}_{18} & 0.603 \\
\mathrm{x}_{16} & 0.593\end{array}$ & $\begin{array}{rr}\mathrm{x}_{5} & 0.722 \\
\mathrm{x}_{24} & 0.617 \\
\mathrm{x}_{4} & 0.504\end{array}$ & $\begin{array}{cc}\mathrm{x}_{2} & 0.709 \\
\mathrm{x}_{1} & 0.654 \\
\mathrm{x}_{9} & -0.607 \\
\mathrm{x}_{7} & -0.448\end{array}$ & $\begin{array}{rr}\mathrm{x}_{3} & 0.623 \\
\mathrm{x}_{8} & 0.445 \\
\mathrm{x}_{21} & -0.311 \\
\mathrm{x}_{11} & -0.339 \\
\mathrm{x}_{20} & -0.532\end{array}$ & $\mathrm{x}_{32} \quad 0.712$ \\
\hline $\begin{array}{l}\text { Sample } \\
\text { Scores }\end{array}$ & $\begin{array}{ll}\mathrm{x}_{14} & 0.303 \\
\mathrm{x}_{13} & 0.274 \\
\mathrm{x}_{17} & 0.235 \\
\mathrm{x}_{12} & 0.214\end{array}$ & $\begin{array}{cc}\mathrm{x}_{26} & 0.251 \\
\mathrm{x}_{11} & 0.163 \\
\mathrm{x}_{33} & 0.149 \\
\mathrm{x}_{34} & 0.129 \\
\mathrm{x}_{30} & -0.211\end{array}$ & $\begin{array}{ll}\mathrm{x}_{29} & 0.315 \\
\mathrm{x}_{27} & 0.285 \\
\mathrm{x}_{31} & 0.251 \\
\mathrm{x}_{10} & 0.247 \\
\mathrm{x}_{18} & 0.214\end{array}$ & $\begin{array}{rr}\mathrm{x}_{5} & 0.378 \\
\mathrm{x}_{24} & 0.257\end{array}$ & $\begin{array}{rr}\mathrm{x}_{2} & 0.375 \\
\mathrm{x}_{1} & 0.306 \\
\mathrm{x}_{9} & -0.056 \\
\mathrm{x}_{7} & -0.127 \\
\mathrm{x}_{27} & -0.411\end{array}$ & $\begin{array}{rr}\mathrm{x}_{31} & 0.313 \\
\mathrm{x}_{3} & 0.277 \\
\mathrm{x}_{8} & 0.246 \\
\mathrm{x}_{21} & -0.243 \\
\mathrm{x}_{20} & -0.250 \\
\mathrm{x}_{27} & -0.408 \\
\end{array}$ & 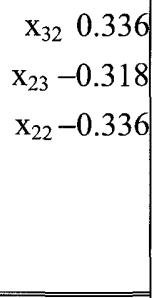 \\
\hline PAIs & PCl & PC2 & PC3 & PC4 & PC5 & PC6 & PC7 \\
\hline $\begin{array}{c}\text { Eigenvalue } \\
\text { Proportion (\%) } \\
\text { Accumulated P. (\%) }\end{array}$ & $\begin{array}{r}7.123 \\
20.949 \\
20.949 \\
\end{array}$ & $\begin{array}{r}4.516 \\
13.282 \\
34.231 \\
\end{array}$ & $\begin{array}{r}4.345 \\
12.780 \\
47.011 \\
\end{array}$ & $\begin{array}{r}3.188 \\
9.378 \\
56.389 \\
\end{array}$ & $\begin{array}{r}2.930 \\
8.617 \\
65.006 \\
\end{array}$ & $\begin{array}{r}2.872 \\
8.448 \\
73.454 \\
\end{array}$ & $\begin{array}{r}2.144 \\
6.307 \\
79.761 \\
\end{array}$ \\
\hline $\begin{array}{c}\text { Factor } \\
\text { Loadings }\end{array}$ & $\begin{array}{ll}\mathrm{x}_{27} & 0.897 \\
\mathrm{x}_{10} & 0.864 \\
\mathrm{x}_{29} & 0.802 \\
\mathrm{x}_{30} & 0.793 \\
\mathrm{x}_{31} & 0.724\end{array}$ & $\begin{array}{ll}\mathrm{x}_{13} & 0.732 \\
\mathrm{x}_{17} & 0.723 \\
\mathrm{x}_{14} & 0.702 \\
\mathrm{x}_{12} & 0.691 \\
\mathrm{x}_{15} & 0.571 \\
\mathrm{x}_{16} & 0.538\end{array}$ & $\begin{array}{rr}\mathrm{x}_{11} & 0.846 \\
\mathrm{x}_{26} & 0.803 \\
\mathrm{x}_{20} & 0.780 \\
\mathrm{x}_{34} & 0.732 \\
\mathrm{x}_{33} & 0.584 \\
\mathrm{x}_{6} & 0.487 \\
\end{array}$ & $\begin{array}{rr}\mathrm{x}_{5} & 0.761 \\
\mathrm{x}_{24} & 0.690 \\
\mathrm{x}_{4} & 0.571 \\
\mathrm{x}_{18} & 0.545\end{array}$ & $\begin{array}{ll}\mathrm{x}_{2} & 0.809 \\
\mathrm{x}_{1} & 0.766\end{array}$ & $\begin{array}{rr}\mathrm{x}_{7} & 0.719 \\
\mathrm{x}_{25} & 0.671 \\
\mathrm{x}_{8} & 0.607 \\
\mathrm{x}_{9} & 0.512\end{array}$ & $\begin{array}{rr}\mathrm{x}_{32} & 0.764 \\
\mathrm{x}_{3} & 0.731\end{array}$ \\
\hline $\begin{array}{l}\text { Sample } \\
\text { Scores }\end{array}$ & $\begin{array}{cc}\mathrm{x}_{27} & 0.353 \\
\mathrm{x}_{10} & 0.306 \\
\mathrm{x}_{29} & 0.233 \\
\mathrm{x}_{17} & -0.254\end{array}$ & $\begin{array}{cc}\mathrm{x}_{17} & 0.431 \\
\mathrm{x}_{13} & 0.317 \\
\mathrm{x}_{12} & 0.275 \\
\mathrm{x}_{14} & 0.263 \\
\mathrm{x}_{15} & 0.141 \\
\mathrm{x}_{16} & 0.061 \\
\mathrm{x}_{29} & -0.224 \\
\mathrm{x}_{27} & -0.247\end{array}$ & $\begin{array}{rr}\mathrm{x}_{20} & 0.291 \\
\mathrm{x}_{26} & 0.201 \\
\mathrm{x}_{11} & 0.183 \\
\mathrm{x}_{17} & -0.236\end{array}$ & 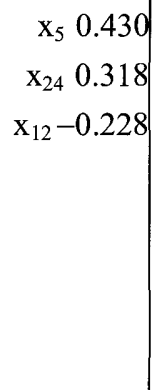 & $\begin{array}{ll}\mathrm{x}_{2} & 0.433 \\
\mathrm{x}_{1} & 0.356\end{array}$ & 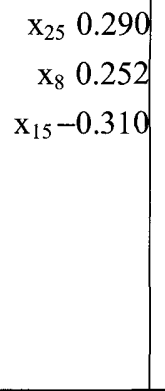 & $\begin{array}{rr}\mathrm{X}_{32} & 0.367 \\
\mathrm{x}_{3} & 0.289\end{array}$ \\
\hline
\end{tabular}

Note 1. Only element scores characterizing each factor are shown.

2. SPSS 10.0 was used for calculation. 
similar effect elements, while they had different effect elements from $\mathrm{x}_{17}$ IDIS.

Patterns of similarity between cause and effect elements were identified by interpreting the results for the extracted PCs. This could easily be done by applying PCA to the total relation matrix. No similarities in cause and effect patterns in any element can be found by merely observing the total relation matrix, the relation index, or the influence index with the DEMATEL method. Therefore, applying PCA with the DEMATEL method would be more useful.

\section{Impact of Information Transfer}

Farmers and civil servants or staff members of PAIs basically evaluated the impact mechanisms for beef cattle farming and prevailing conditions the same. However, farmers evaluated $\mathrm{x}_{16}$ IITMIS as an important element in beef cattle farming. $x_{16}$ IITMIS had a relatively strong impact compared with the other information elements because it was fundamental to the input sector of beef cattle farming and had an influence on product and management results.

Links, which were "the improvement in information services on beef or calf prices result in increased managerial salaries" and "the improvement in information services on domestic or imported beef lead to reduced the production costs" , were very weak. Efficient use of information in beef cattle farming will be a subject for future study.

The Analytic Hierarchy Process (AHP) was used to support complex evaluations and the decision process by doing pair-wise comparisons of elements and by ranking them on the basis of numerical scores (Kinoshita 2000; Shin et al. 2002). AHP was used to evaluate the priority of information as listed in Table 4. The weights for the criteria and the scores for the alternatives have been considered as decision elements in the second step of the decision process. To find the relative importance of information elements, the pair-wise comparison scale was divided into three levels, where scores of 1,3 , and 5 respectively mean "Both elements are equally important to beef cattle farming" , "Element $i$ is slightly more important to beef cattle farming than element $j$ ", and "Element $i$ is significantly more important to beef cattle farming than element $j$ ". If element $j$ is more important than element $i$, reciprocal numbers are used. Each set of comparisons for a level with $\mathrm{n}$ elements requires ${ }_{n} C_{2}$ judgments. Positive reciprocal matrix A of pair-wise comparisons is constructed (Eq. 5) in this way. The columns of matrix $A$ are summed, and each $a_{i j}$ is converted to a percentage of

Table 4 AHP Analysis Result

\begin{tabular}{|c|c|c|c|c|}
\hline & \multirow[b]{2}{*}{ Farmers } & \multicolumn{3}{|c|}{ PAIs } \\
\hline & & Total & $\begin{array}{c}\text { Civil servants } \\
\text { of NATC }\end{array}$ & $\begin{array}{c}\text { Staff members } \\
\text { of ACA }\end{array}$ \\
\hline $\mathrm{x}_{12}$ IDIBIS & 0.402 & 0.219 & 0.180 & 0.239 \\
\hline $\mathrm{x}_{13}$ IBPIS & 0.169 & 0.129 & 0.129 & 0.119 \\
\hline $\mathrm{x}_{14}$ ICPIS & 0.137 & 0.136 & 0.141 & 0.112 \\
\hline $\mathrm{x}_{15}$ IPIS & 0.135 & 0.173 & 0.189 & 0.144 \\
\hline $\mathrm{x}_{16}$ IITMIS & 0.069 & 0.139 & 0.185 & 0.107 \\
\hline $\mathrm{x}_{17}$ IDIS & 0.087 & 0.204 & 0.176 & 0.279 \\
\hline $\mathrm{CI}$ & 0.046 & 0.051 & 0.070 & 0.074 \\
\hline (CR) & $(0.037)$ & $(0.041)$ & $(0.056)$ & $(0.060)$ \\
\hline
\end{tabular}

Note 1. Pair-wise comparisons scale was divided into three levels, where scores of 1, 3, and 5 .

2. CI : Consistency index, $\mathrm{CR}$ : Consistency ratio.

3. $\mathrm{CR}=\mathrm{CI} /$ Random Consistency $(\mathrm{R})$.

4. Excel program was used for calculation. 
its column total. The rows are averaged and the averages of these rows determine the priority for ordering corresponding elements. The higher the average, the more important that element is. AHP enables the analyst to evaluate the goodness of judgments with the consistency index $(C I)$. A $C I$ of 0.10 or less implies a more consistent judgment, which is acceptable.

$$
\begin{aligned}
& \begin{array}{llll}
\mathrm{A}_{1} & \mathrm{~A}_{2} & \ldots & \mathrm{A}
\end{array} \\
& A_{1}\left[\begin{array}{llll}
w_{1} / w_{1} & w_{1} / w_{2} & \cdots & w_{1} / w_{n}
\end{array}\right]
\end{aligned}
$$

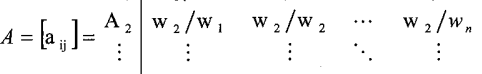

$$
\begin{aligned}
& A_{n}\left[w_{n} / w_{1} \quad w_{n} / w_{2} \quad \cdots \quad w_{n} / w_{n}\right.
\end{aligned}
$$

where

$$
a_{i j}=w_{i} / w_{j}, \quad a_{j i}=1 / a_{i j}, \quad W=\left[\begin{array}{c}
w_{1} \\
w_{2} \\
\vdots \\
w_{n}
\end{array}\right]
$$

First, checking the priority values, the farmers' case indicates that $40.2 \%$ of the information weight is on $\mathrm{x}_{12}$ IDIBIS, $16.9 \%$ on $\mathrm{x}_{13}$ IBPIS, $13.7 \%$ on $x_{14}$ ICPIS, $13.5 \%$ on $x_{15}$ IPIS, $8.7 \%$ on $x_{17}$ IDIS, and $6.9 \%$ on $x_{16}$ IITMIS. In the PAIs' case, $21.9 \%$ of the information weight is on $\mathrm{x}_{12}$ IDIBIS, $20.4 \%$ on $\mathrm{x}_{17}$ IDIS, $17.3 \%$ on $\mathrm{x}_{15}$ IPIS, $13.9 \%$ on $\mathrm{x}_{16}$ IITMIS, $13.6 \%$ on $\mathrm{x}_{14}$ ICPIS, and $12.9 \%$ on $\mathrm{x}_{13}$ IBPIS. The NATC civil servants and the ACA staff members evaluated the priority of information differently. While the civil servants regarded $x_{15}$ IPIS as being the most important, the ACA staff members thought $x_{17}$ IDIS was the most important. The farmers and civil servants or staff members of PAIs regarded $x_{12}$ IDIBIS to be the most important. $x_{12}$ IDIBIS was thought to represent the most fundamental information with respect to beef products.

The PAIs' civil servants or staff members regarded $x_{17}$ IDIS as being more important than the farmers did because they were anxious about the strong impact a disease outbreak would have on the district from the standpoint of the public. They took little notice of $\mathrm{x}_{16}$ IITMIS in the AHP analysis. However, $x_{16}$ IITMIS had been evaluated as having a relatively strong impact on the six kinds of information in the DEMATEL analysis. Neither the farmers nor civil servants and staff members of PAIs considered the importance of information in considering its impact.

Generally speaking, the civil servants and staff members of PAIs evaluated all the information equally, while the farmers attached greater importance to $x_{12}$ IDIBIS and paid little attention to $\mathrm{x}_{16}$ IITMIS. One explanation is that their different positions with regard to beef cattle farming led to differences in their evaluations.

The importance of the information itself in the AHP results was not the same as the magnitude of its impacts in the DEMATEL ones. In the DEMATEL analysis, $x_{16}$ IITMIS was the largest and $x_{14}$ ICPIS was the smallest influence element $\left(D_{i}\right)$, which meant the magnitude. However, in the AHP result, $x_{12}$ IDIBIS was the most and $x_{16}$ IITMIS (farmers) and $x_{13}$ IBPIS (PAIs) were the least important element in beef cattle farming.

\section{Conclusion}

The DEMATEL method is a good technique for analyzing the correlation between pairs of elements. The dual-fold purpose of this study was to investigate whether there was a correlation between agricultural information and beef cattle farming and to analyze what improving information services had an effect on beef cattle farming. Moreover, features or correlations that were based on the similarity of cause or effect element groups were confirmed by applying PCA to the total relation matrix. The results we obtained are summarized in Fig. 3 .

Evaluations of the impact mechanism between beef cattle farming and prevailing conditions were fundamentally the same for the farmers or the civil servants and staff members of PAIs. All information elements had large relation index values, which were greater than average and which indicated importance. However, all their influence index values were negative and therefore belonged to the effect group. Both responding groups thought that the change in elements involving beef cattle farming easily improved information services, whereas it did not affect beef cattle 
farming or prevailing conditions.

The general positioning of all elements in the total system could be confirmed by applying the original DEMATEL method, whereas it was difficult to investigate features that were based on the cause-effect relationship of all elements. PCA was applied to the total relation matrix to find out the extent of the cause- effect relationship on the results. The features or correlations within all elements, based on patterns of similarity between the cause or effect groups, were then confirmed (See Fig.3). It was clear that the application of not only the DEMATEL method but also PCA would be more useful.

The evaluation of the information itself in the

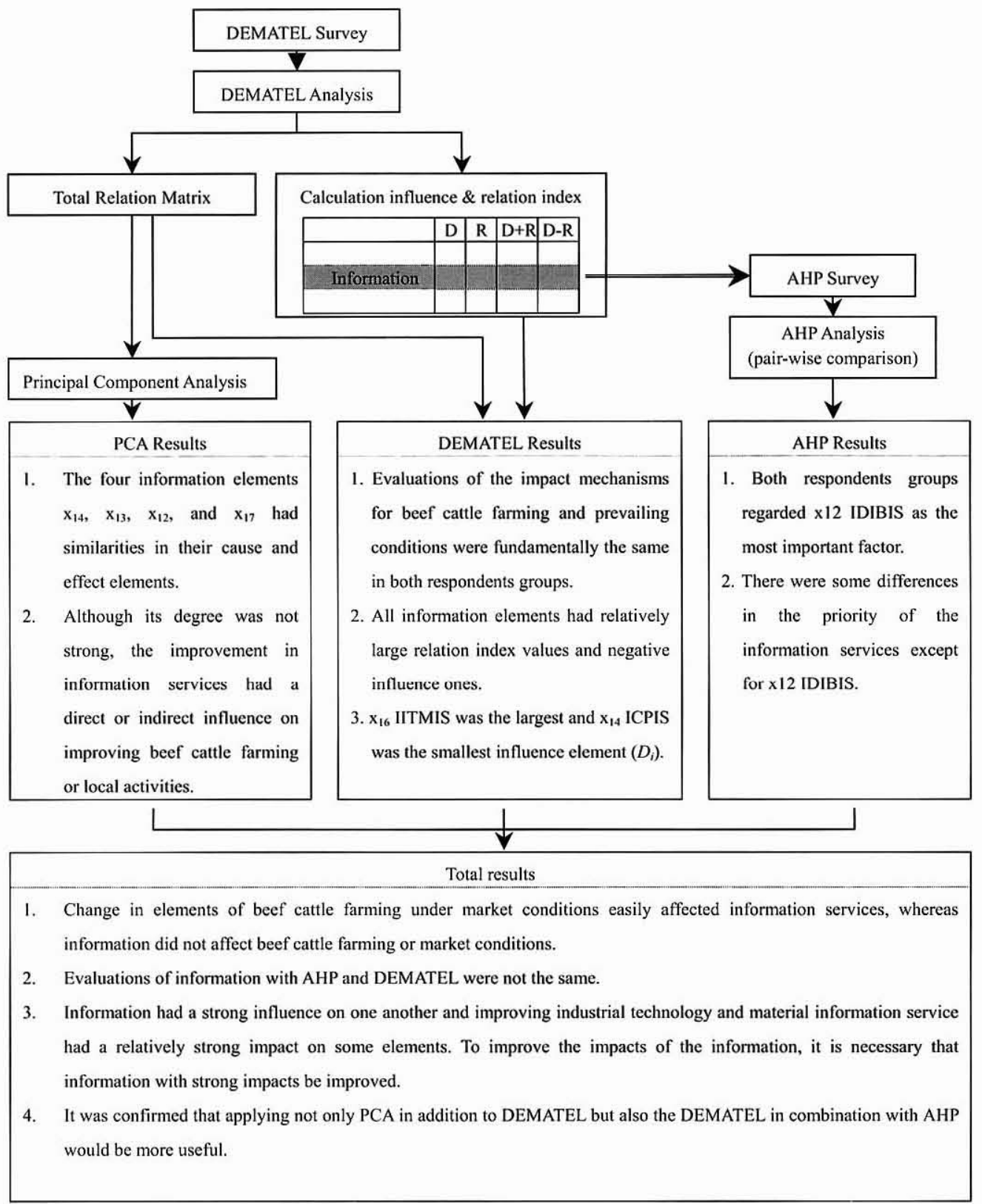

Fig. 3 A general flow chart of the analysis 
AHP results was not the same as the magnitude of its impacts in the DEMATEL analysis. There is the possibility that the importance of all elements was not evaluated from the viewpoint of impact.

Although agricultural information spread by computers and the information superhighway has been improved and many kinds of information services have been offered by public agencies, its application leaves much to be desired. The spread of computers within the farming community is still lower than the national average and only a few farmers are limitedly utilizing them. Not only the construction and preparation of an information network but also the education of farmers is necessary to solve such problems. The agricultural public agencies should be in charge of the development of agricultural databases and software, training of computer and its software for practical uses and a quick and useful information services.

We found that information has an influence on one another and that improving industrial technology and material information services ( $\mathrm{x}_{16}$ IITMIS) has a relatively strong impact on various elements. To improve the impacts of agricultural information, it is necessary that information with strong impact on beef cattle farming be improved.

\section{References}

Cho Y. (2002) A Study For Structurizing Design Factors Comparison of DEMATEL theory and KJ theory, Journal of Design Science Research, Vol. 5, No. 1, 49-57.

Hoshino S. (1992) Extension Mechanism of Direct Effects of Land Consolidation Project - A Case study of Nagi Town, Okayama Prefecture, Journal of Rural Planning Association, Vol. 11, No. 2, 6-19.

Hwang K. and Lee K. (2002) The evaluation for Resort participation of the aging population by the Application of DEMATEL method, Journal of Tourism Research, Vol. 14, No. 2, 289-302.

Kang K. (2002) A Study on the Status and the Direction of Agricultural Information Technology Workforce Development in Korea, Journal of Korean Agricultural Education, Vol. 34, No. 2, 86-97.

Kinoshita E. (2000) Introduction to AHP, JUSE Press, $5-28$.
Korean Ministry of Agriculture and Forestry. (1998) Policy Data on the agricultural information. $<$ http:/ /www.maf.go.kr/>, browsed on Nov. 7, 2005.

Lin C. and Wu W. (2004) A Fuzzy Extension of the DEMATEL Method for Group Decision-Making, Journal of Operations Research Society of Taiwan, Conference 2004, 843-852.

Monma T. (1992) The Evaluation of Farm Road Development by the Application of DEMATEL Method, Journal of Rural planning Association, Vol. 11, No. 3, 7-20.

Oh Y., Lee W., and Honda Y. et al. (1998) A Study on the Theme and Estimation of Planning in the Cities of Steep Sites in Korea and Japan - Focus on DEMATEL and Quantification Theory, Journal of Korea Planners Association, Vol. 33, No. 3, 331-346.

Paul A. S. (1975) A General Field Theory of Migration United States, 1955-1960, Economic Geography, Vol. 51, 1-16.

Shin Y., Park M., and Cheon D. (2002) An Application of the AHP to the selection of Animal Waste Facility, Korean Journal of Agricultural Management and Policy, Vol. 29, No. 1, 118-137.

Tamura H., Nagata H., and Akazawa K. (2003) Structural Modeling and Systems Analysis of Various Factors for Realizing Safe, Secure and Reliable Society, The 3rd International Conference on DSTIS, 99-110.

William L. G. and Duane F. M. (1963) Factor-Analytic Study of the Connectivity of a Transportation Network, Papers of the Regional Science Association, Vol. XII, 231-238.

Received Dec. 282005

Accepted Jly.13 2006

Economical and social information. 


\title{
DEMATEL 法と主成分分析法及びAHP 法による韓国に おける肉用牛経営の波及効果メカニズムと農業情報の 重要度評価に関する考察
}

\author{
金 容黑
}

鳥取大学大学院連合農学研究科 $\bar{T} 680-8553$ 鳥取県鳥取市湖山町南 4 丁目 101

\section{摘要}

本論文では韓国肉用牛経営を対象として，情報が肉用牛経営およびそれを巻く環境条件 との間でどのような相互関係を備えているか, そして情報機能の充実・強化が肉用牛経営 に対して持つ効果をDEMATEL 法, 主成分分析法及びAHP 法を適用して明らかにした.

DEMATEL 法による計算結果をみると農民や農業関連機関の担当者との間で肉用牛経営 と肉用牛経営を取り巻く環境の間の波及効果の評価は基本的に違いがない。全ての情報要 因は平均值以上の大きな関連度をもっている。しかし, 情報要因の影響度はマイナスで, 影響先要因として位置づけられる。農民や農業関連機関の担当者は，肉用牛経営を取り巻 く環境は肉用牛に関する情報の充実・強化には影響を与えるが，作成・公表された情報は， 肉用牛経営やそれを取り巻く環境にあまり大きな効果をもたらさないと考えている，ただ し, 情報はその提供・機能充実がある程度は波及効果を与えていていることも明らかに なった。このように波及効果を分析するうえで, DEMATEL 法は有効であることが確認で きた.

また，DEMATEL 法で計算される総合影響行列を主成分分析にかける方法を提示して，影 響を受ける相手側要因の類似性や，影響を与える相手側要因の類似性に基づいて，要因相 互間の関係や特徵をより詳細に把握することができた。さらに，AHP 法による重要性把握 では，被調査者は波及効果まで考慮して評価していないことが明らかになった．

パソコンやインターネットの普及で農業情報の基盤は向上し，様々な情報が農業関連機 関などから提供されているが，その利用はまだ不十分である。農村のパソコン普及率は韓 国内の平均值以下で，それを利用する農民も少ない。その問題を解決するためには情報の ネットワーク整備だけではなく，農民の教育も必要である.

キーワード

情報サービス, 肉用牛経営, DEMATEL 法, 主成分分析, AHP 法,

*Corresponding Author E-mail: carfinkim@hotmail.com 